\title{
Adoption of food safety practices in the informal milk processing units of Haryana, India - A value chain approach
}

\author{
Amit Thakur ${ }^{1}$, Anil Kumar Dixit ${ }^{1}$, AK Sharma ${ }^{1}$, Shiv Kumar ${ }^{2}$, R Sendhil ${ }^{3}$ and AK Singh ${ }^{1}$
}

Received: 31 July 2021 / Accepted: 21 November 2021 / Published online: 21 December 2021

(C) Indian Dairy Association (India) 2021

\begin{abstract}
In this paper, we analysed how the adoption level of food safety practices varies with milk procurement system in the informal milk processing sector and also developed a composite food safety index (FSI) deliberating the interplay of factors and actors. Primary data were collected from value chain actors, viz., small and micro dairy processing units (main actors), milk supplier, i.e., dairy farmer and milk vendors (upstream actors) and traders (downstream actors) in Karnal district of Haryana state of India. FSI of two identified milk procurement systems, viz., (i) own collection centres, and (ii) private vendors were compared. Processing units with own collection centres in production catchments have been able to establish better linkages with dairy upstream actors and resulted in better overall FSI (0.66) than those processing units procuring milk from private vendors (with FSI as 0.51). Further, the profitability of the processing unit is positively associated with the FSI, as consumers are willing to pay higher prices for safe milk. There was a need to design efficient milk procurement systems; design and development of efficient milk transport systems and processing technology along with
\end{abstract}

${ }^{1}$ ICAR-National Dairy Research Institute, Karnal-132001 (Haryana), India

${ }^{2}$ ICAR-National Institute of Agricultural Economics and Policy Research, New Delhi- 110012

${ }^{3}$ ICAR-Indian Institute of Wheat and Barley, Karnal-132001 (Haryana), India

Anil Kumar Dixit $(\square)$

Principal Scientist, Dairy Economics, Statistics and Management Division, ICAR-National Dairy Research Institute, Karnal-132001 (Haryana), India, E-mail: poojanilwe@gmail.com training in post-milking handling for small vendors and processors for better food safety compliance in the milk value chain of the informal sector.

Keywords: Food Safety, Milk, Procurement system, Value Chain

\section{Introduction}

The journey of the world's largest milk producing country started from a novel idea of "Operation Flood" way back in 1970. It has transformed India from a milk deficient nation to surplus. India advanced in milk production and surpassed the rest of the world, with $18 \%$ share in global production. Milk is recognised as a complete food for human beings, as it provides essential nutrients (energy, proteins, vitamins and minerals) in a significant amount than other foods of animal origin (Pandey and Voskuil, 2011). Milk production, in India, has attained a compounded annual growth rate (CAGR) of $4.5 \%$ over the last 20 years, much higher than the world (FICCI, 2020). However, consumer concern and awareness about milk quality and safety in recent years - attracted attention of the dairy industry (Malathi, 2017). Food safety is one of the essential components of food security (Carlsson et al. 2005; Goldberg and Roosen, 2007; Marette et al. 2008; FAO, 2009; David and David, 2017).

Milk is a perishable commodity, which deteriorates easily if not handled properly, and affects the quality of the dairy products (Murphy et al. 2016). Milk can be contaminated by microorganisms at any stage in the milk value chain from production to consumption and it can lead to serious food borne diseases (Bereda et al. 2012). In developing countries, compliance with food safety measures is found to be elusive along the value chain (Janssen and Swinnen, 2019; Gupta et al. 2014; Handschuch et al. 2013). Food Safety and Standards Authority of India (FSSAI), a regulatory agency - enforcing food safety standards in India, in a survey found that nearly $70 \%$ of fluid milk samples did not conform to standards (Centre for Science and Environment, 2012). Demand for safe and quality milk products (Kohli and Garg, 2015), higher income (Gandhi and Zhou, 2013), and increasing integration with the global economy (FAO, 2013), favours food safety. Modernised retailing and speedy urbanisation (Reardon 
and Timme, 2014), in India is forcing the Government for better compliance with food safety measures.

Food safety compliances enhance the competitiveness of small dairy holders (USDA, 2017), and win consumer confidence in the integrity of the value chain (John, 2012; Thakur et al. 2021). To improve the food safety aspect in developing countries, major emphasis has been given to the production activities (Unnevehr, 2014). Studies in Indian dairy sector on food safety issues by Kumar et al. $(2011,2017,2020)$ identified its drivers at farm level, impacts on performance (milk yield, profitability) of dairy farms suggest an integrated approach, which ensures food safety starting from production till consumption point.

In India, more than $70 \%$ of milk marketable surplus sold through informal channel-consists of vendors, small scale processing units, local traders, where quality is a big concern (Chellappa and Haran, 2018). With multiple actors in the value chain, few questions arise: (i) what is the extent of food safety measures (FSM) adopted by dairy value chain actors? (ii) whether selection of varying procurement systems by processing units - make any difference in composite food safety index? However, past studies did not cover the perspective of food safety measures in the entire milk value chain. In this backdrop, it became essential to address the food safety issues of milk value chains of the informal sector with special emphasis on post-production aspects. Specially, this paper develops deep into the status of food safety practices (FSP) adoption by actors/stakeholders in different stages of (i) own procurement, and (ii) private vendor chain on the basis of procurement pattern by processing units. In the milieu, a composite food safety index was developed and compared for both the chains at different stages as well as for the whole chain. The purpose is to find out which of the chain(s) are complying with safety practices effectively. The knowledge emanating from this study would provide deep insights into implementation of food safety practices and would be helpful to policymakers and planners to formulate policies and programmes to promote safe production of milk and milk products.

\section{Data and Methodology}

The study was carried out in Haryana state of India pertaining to year, 2019. Haryana has the highest average milk productivity of Buffalo $(8.39 \mathrm{~kg} / \mathrm{day})$ and ranks $2^{\text {nd }}$ in terms of per capita milk availability (930 g/day) in the country (NDDB, 2017). Moreover, the share of income earned by household from livestock was (18\%) higher as compared to the national average (11\%) (Singh et al. 2017). In this study, the Karnal district of Haryana was purposively selected (Fig.1) for primary data collection.

The study region is having a well-established mix of formal and informal milk processing units and earmarked as cluster for milk processing by Government of Haryana ( $\mathrm{GoH}, 2019)$. For assessing compliance of milk safety practices in the informal processing sector, 27 small dairy processing units were randomly selected using random walk method. These processing units have established backward linkages with farmers and vendors for getting uninterrupted supply of milk. To trace level of food safety measures adopted in upstream actors: 50 milk supplier (dairy farmer and milk vendors) and downstream actors: 20 traders, were selected for detailed data collection. Overall, a sample of size 97 actors involved in milk value chain was studied to develop the composite food safety index for milk and milk products. The primary data collected cover a wide range of information regarding stakeholder's participation in the milk value chain, various food safety practices adopted along the chain. Information on socioeconomic profile of stakeholder such as age, education, experience in dairying, etc., were also collected. The key variables used in study included food safety index, value chain actors, value added products, value chain, profit, education of owners of processing units, age, experience in milk processing. The details of conceptual framework and estimation procedure are given as below.

\section{Adoption of food safety practices across the informal milk value chain}

To assess the status of FSP adopted by different stakeholders in the milk value chain, potential practices were first identified through literature review followed by consultation with the experts. About 70 scientific practices from literature (Burke et al. 2018; Asselt et al. 2014; FAO, 2013; FSSAI, 2011; NDDB, 2016), which control chemical or biological loss to milk and milk products along the milk value chain (Griffiths, 2010) were listed for food safety practices. Least important practices were omitted at initial stage and finally 39 practices retained to access the food safety score (Table 1). Further, importance of safety practices was measured on a three-point continuum (NDDB, 2016), i.e., critical practices (maximum score of 8), major practices (score ranged between 5-7) and minor (score of 4 or less) from compliance point of view with the help of experts. Finally, per cent adoption of food safety practices at each stage by value chain actors was assessed.

These selected practices were assessed value chain wise and also unit operations wise, viz., i) milking and post milking ii) milk transport and reception iii) processing operations and marketing (Table 1). A norm for compliance was $85 \%$ for major and $70 \%$ for minor safety practices (NDDB, 2016).

The sources of contamination in raw milk were dairy farm environment, producer's hygiene and instrument used (Gashaw et al. 2018; Lemma et al. 2018; Giffel et al. 2010). Milking and postmilking includes 9 scientific practices for milking, storage temperature after milking, personal hygiene of dairy producers, washing of utensils, etc., which prevent milk contamination (Tadele et al. 2016). Transportation of milk from dairy farms to the processing plants must ensure that temperature must not go 
Fig. 1 District map of Haryana state

Respondent

Sample size

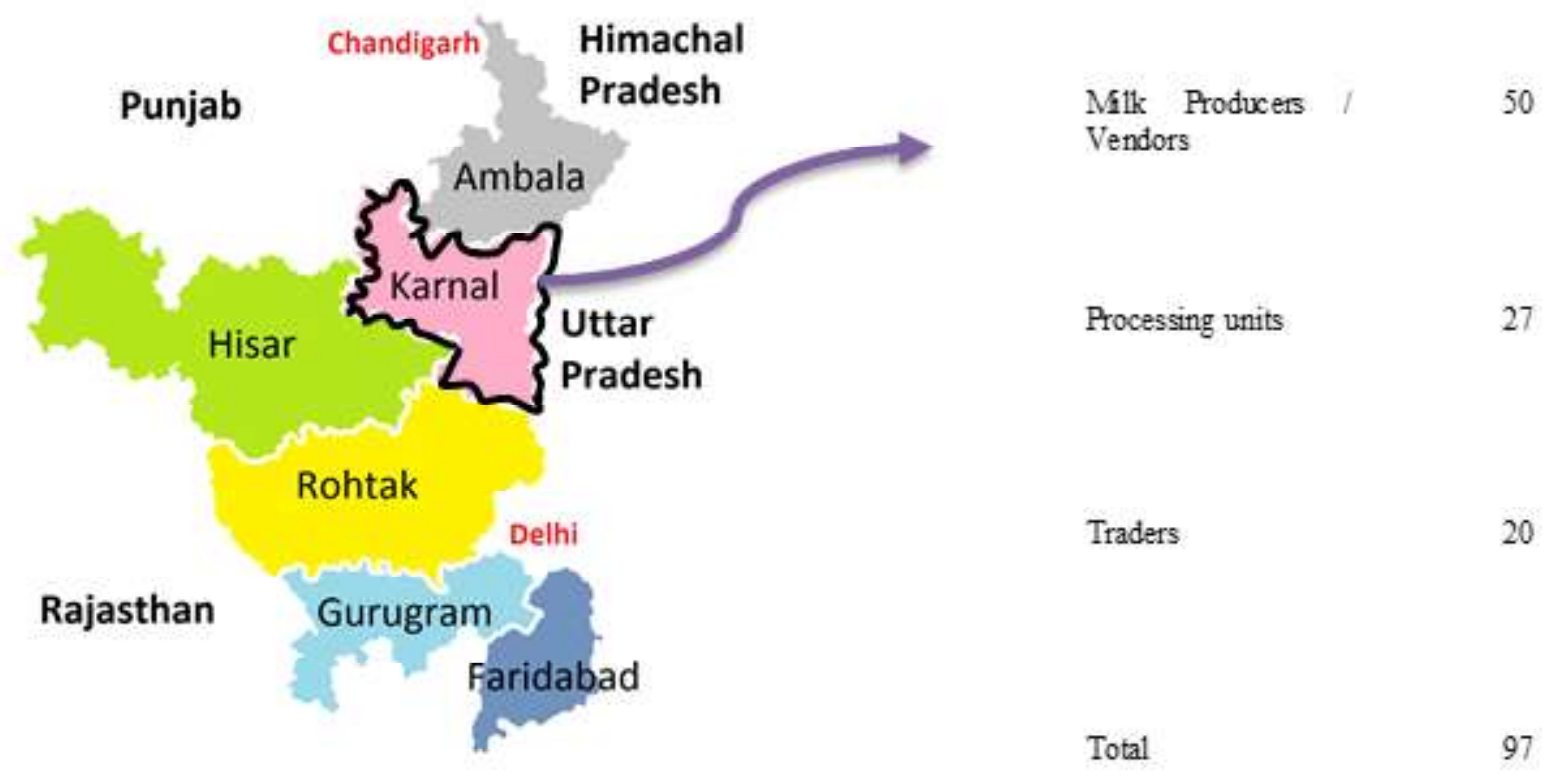

Table 1 Safety practices identified and their adoption across value chain

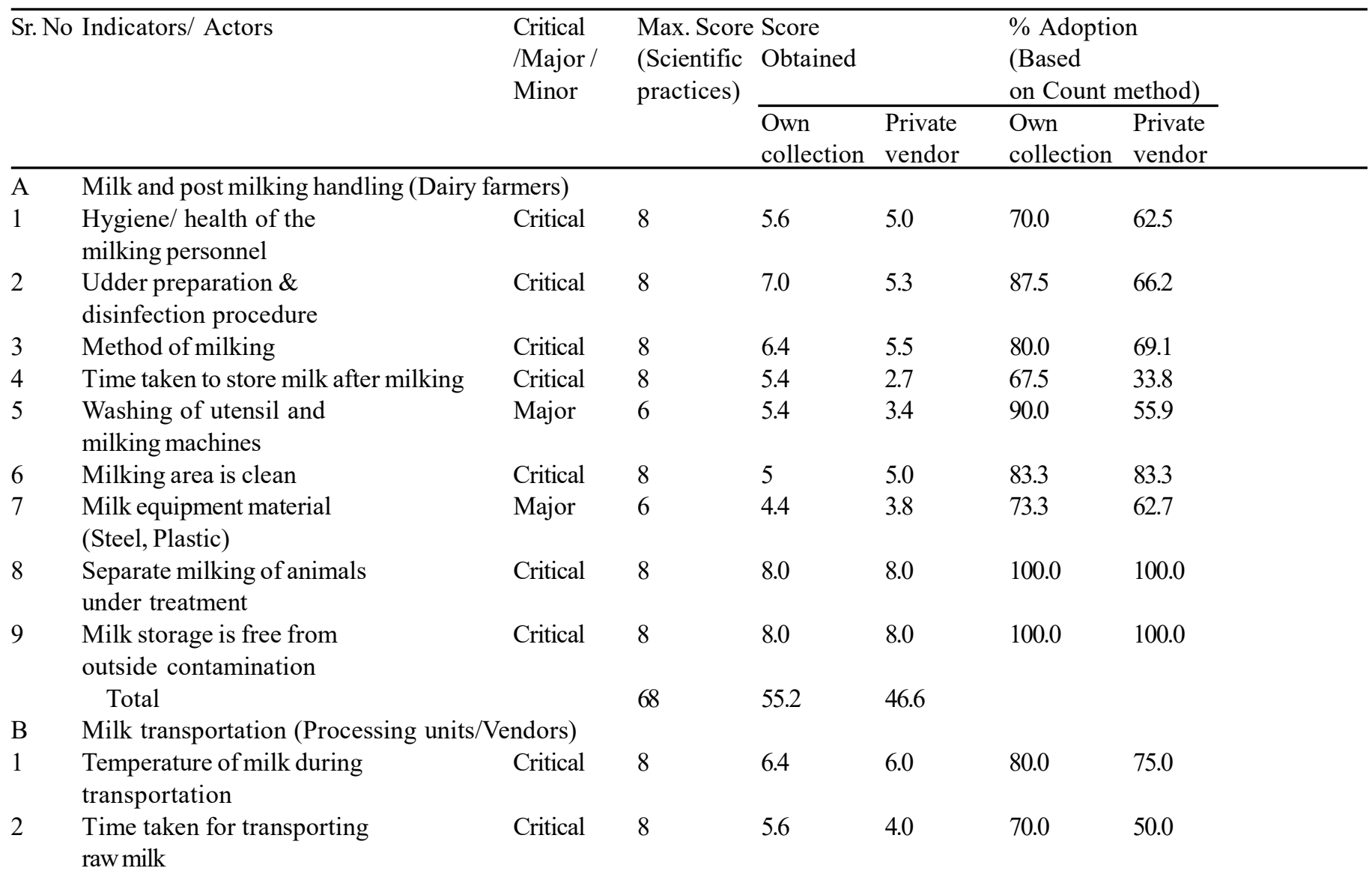




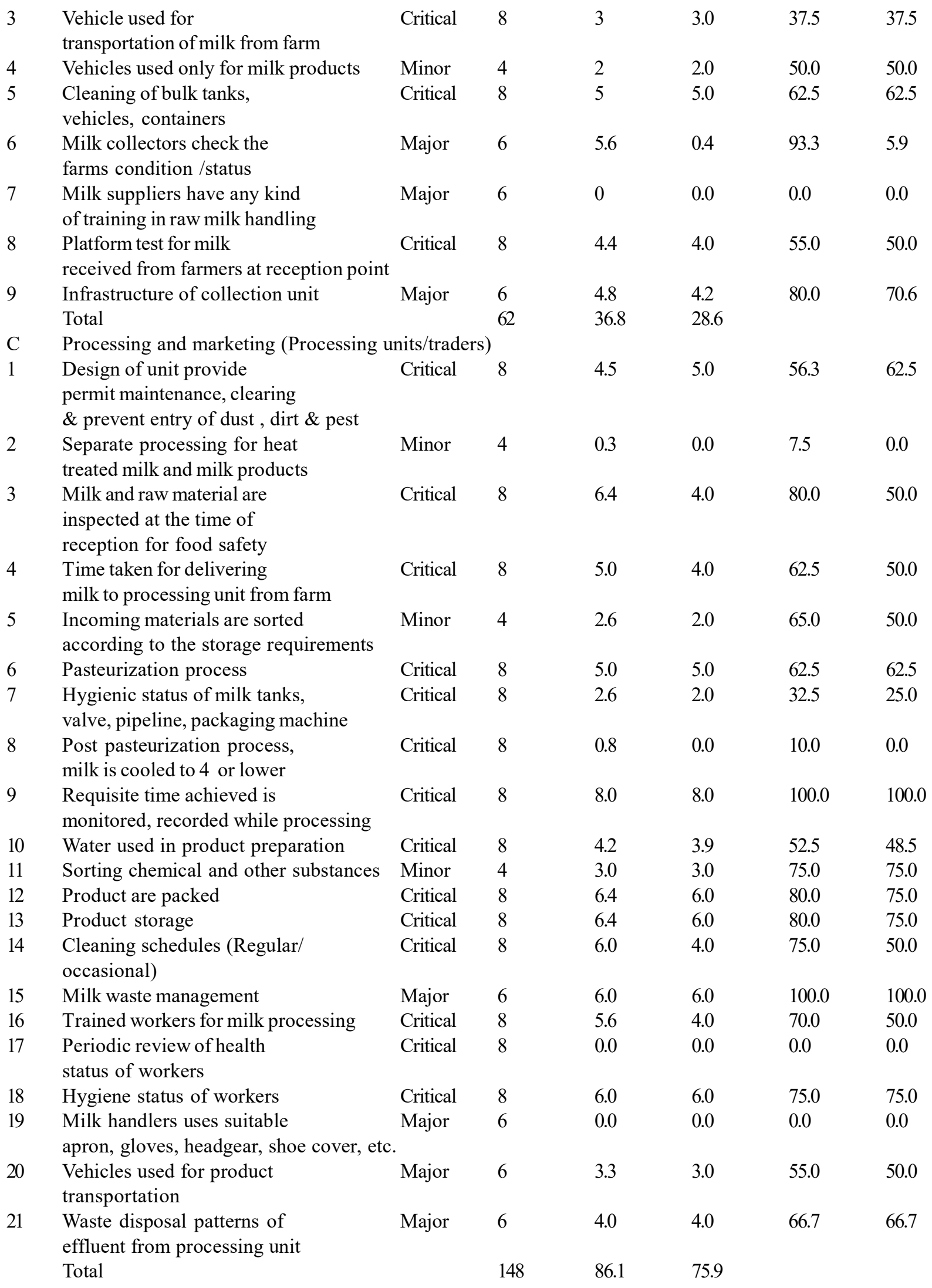


beyond $5^{\circ} \mathrm{C}$ (Ali and Fischer, 2002). To maintain temperature and other hygienic conditions, 9 practices ensuring milk safety during transportation and reception of milk were included.

During processing operation and marketing of dairy products, potential source of contamination were: (i) physical like dirt particles, hair, metal partials, etc. (Kumar et al. 2018), and (ii) microbiological and food borne pathogens (Kamana et al. 2005). Altogether, 21 practices included on quality and hygiene conditions at processing units, training on food handling, pasteurisation of milk, product storage, refrigeration, packaging, milk transport to outlet and subsequently methods used for disposal of by-products/waste material.

To assign a score to each selected practice, opinions from 50 experts (scientists, veterinarians and food technologists) were ascertained. Processing operations and disposal were given a maximum of 148 scores, while milking and post milking practices assigned 68 score and transport activities (62 score) to out of a total score of 278 assigned to all the practices if followed in the value chain.

Safety index was calculated based on the given formula.

Safety index $=\frac{\text { Obtained Score }}{\text { Maximum Obtainable Score }} \quad$ X100

Importance of sub indicator was assessed based on the adoption score. In the case of the dairy processing value chain, processing operation and product disposal share $54 \%$ of safety score, followed by milking and post milking (24\%) and transport and reception (22\%). Computing the safety score in the chain and classifying them in to three different adopter groups of high, moderate and low adopter based on 80 percentile score (high) (Gupta et al. 2014), 60 percentile (moderate) and lesser than 60 percentiles as cut-off for safety score with the consultation of experts. Statistical comparison of the safety scores of selected indicators among two value chains based on (i) own collection and (ii) vendor system of milk procurement was carried out by using t-test with unequal variances. Hypothesis tested that safety scores under two value chains are same and do not differ significantly. The t-statistic for unequal variances of t-test is given by

$$
t=\frac{X_{1}-X_{2}}{\sqrt{\frac{s_{1}^{2}}{n_{1}}}+\sqrt{\frac{s_{2}^{2}}{n_{2}}}}
$$

Here, $X_{1}$ represents the safety score obtained under different indicators in the first value chain and $X_{2}$ represents the safety score of second group indicators. Here, $n_{1}$ and $n_{2}$, represent the numbers of units and $s_{1}^{2}$ and $s_{2}^{2}$ represent variances of the safety scores of units. Unequal variance t-test compares the average value of the two groups, based on the differences in their variances and must be followed over the student t-test, Mann-Whitney U-test (Ruxton, 2006).

\section{Results and Discussion}

\section{Prevailing milk value chain of informal sector}

Dairy processing units are the core actors in the value chain and other actors entail in the value chain are producers, milk suppliers/ vendors, processing units, distributors and consumers. These processing units are enshrined for compliance of safety practices by regulating the processing operations on one hand and encouraging upstream actors (milk producers and vendors) and downstream actors (traders and consumers) of the chain. Milk value chains were classified on the basis of milk procurement pattern followed by the processing units in the study area. Two milk value chains of the informal sector: first own collection and second, private vendor chain were identified. Using Vensim-7 simulation software (Shamsuddoha and Nedelea, 2013) (free version), the identified value chain of informal processing units, viz., (i) value chain of own collection system (Fig. 2) and (ii) value chain of private vendor system (Fig. 3) was mapped with core actors and basic activity performed by them along the chain.

Milk safety in the value chains depends on the safety maintained at each step (Valleva et al. 2005). Hence, prime responsibility of clean and safe milk production lies at farm level. In the first channel, farmers supplied milk to the collection centres of processing units and in the second channel milk was sold to the milk vendors. Milk collection centres is the establishment of some processing units in the production catchments for collecting milk from the producers. Collection centres has the facility of cooling the milk, storage and transportation to the processing units. Private vendors' are one of the important actors in the milk value chain, who are involved in collecting milk from the farmers. They are engaged primarily in direct selling of milk to the end customers and also to the informal processing units, if some quantity is leftout.

Small scale processing units are major stakeholders in the informal milk processing sector. Processing unit owners' exhibits control over the value chain, as they set the quality parameters for milk procurement mainly fat (\%), Solid-not-fat (SNF), control processing operations, provide information backward in the chain and retailing of the dairy products. Processing units procure milk either from collection centres or supplied by private vendors. The role of traders/distributors in the milk value chain is to ensure supply of milk and milk products to the consumers and act as a link between processing units and final consumers. 


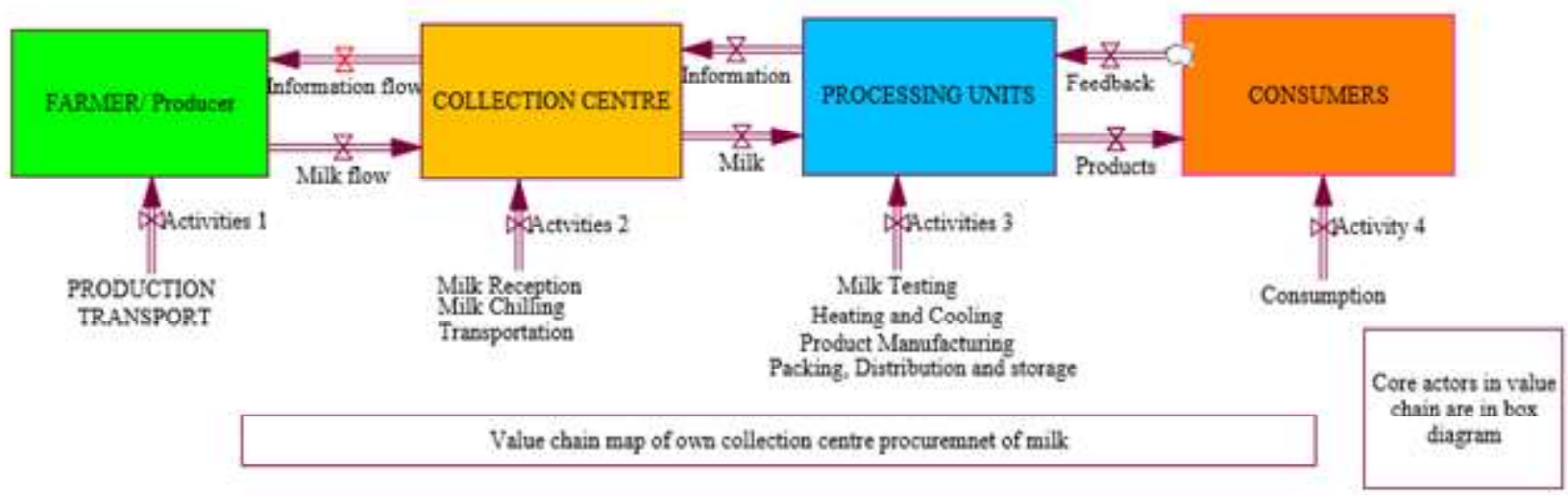

Fig. 2 Value chain of own collection system

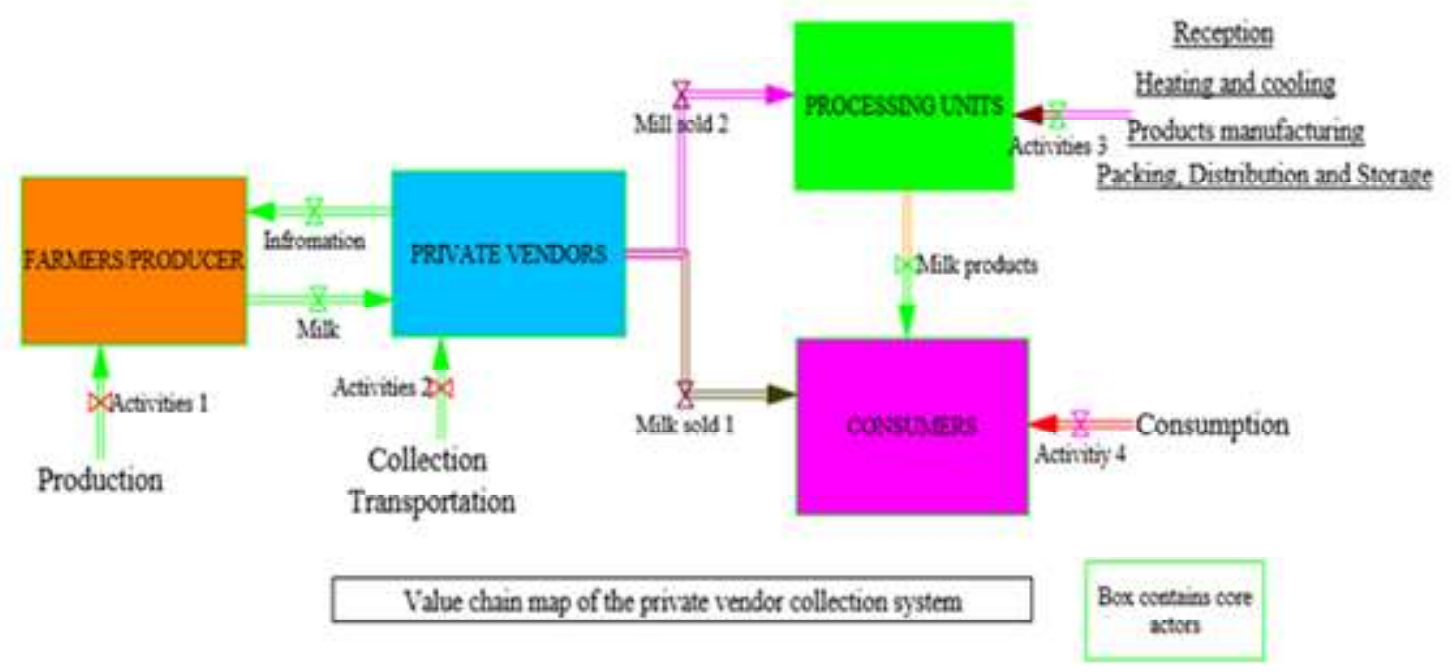

Fig. 3 Value chain of private vendor

Table 2 Food safety index for the milk value chain according to procurement system

\begin{tabular}{|c|c|c|c|c|c|c|}
\hline \multirow[t]{2}{*}{ Indicators } & \multirow{2}{*}{$\begin{array}{l}\text { Overall safety score } \\
\text { Own collection }\end{array}$} & \multicolumn{3}{|c|}{ Variance } & \multirow{2}{*}{$\begin{array}{l}\mathrm{t}- \\
\text { value }\end{array}$} & \multirow{2}{*}{$\begin{array}{l}\mathrm{p}- \\
\text { value }\end{array}$} \\
\hline & & $\begin{array}{l}\text { Private } \\
\text { vendor }\end{array}$ & $\begin{array}{l}\text { Own } \\
\text { collection }\end{array}$ & $\begin{array}{l}\text { Private } \\
\text { vendor }\end{array}$ & & \\
\hline Milking and post milking & $0.81 * * *$ & 0.69 & 0.005 & 0.002 & 4.96 & 0.001 \\
\hline Transport activities & $0.59 * * *$ & 0.46 & 0.004 & 0.001 & 6.3 & 0.0002 \\
\hline Processing and Marketing & $0.58 * *$ & 0.51 & 0.08 & 0.002 & 2.46 & 0.017 \\
\hline Overall Index value & $0.66^{* * *}$ & 0.51 & 0.003 & 0.001 & 5.79 & 0.0001 \\
\hline
\end{tabular}

$* * *(\mathrm{p}<0.01)$ and $* *(\mathrm{p}<0.05)$ significance level

Actors involved, activities performed and benefit-cost structure differ with value chain based procurement systems (Thakur et al. 2021). Likewise, adoption of food safety practices varies with the value chain.

\section{Adoption of food safety practices at each stage of milk value chain}

Food safety practices found to be adopted at farm level are cleaning of utensils, udders before milking, maintaining personal hygiene, cleaning milk shed, etc. Vendors were collecting fresh milk from farmers, washing their milk containers before and after the use. Collection centres of processing units were performing cooling of the milk, storage and transporting milk to processing units by following temperature and time requirements. Personal and vehicle hygiene were maintained at collection centres. Processing units were collecting milk and checking for fat and SNF of milk, adequate storage of milk and milk products. 
Fig. 4 Food safety index and profits from milk sale

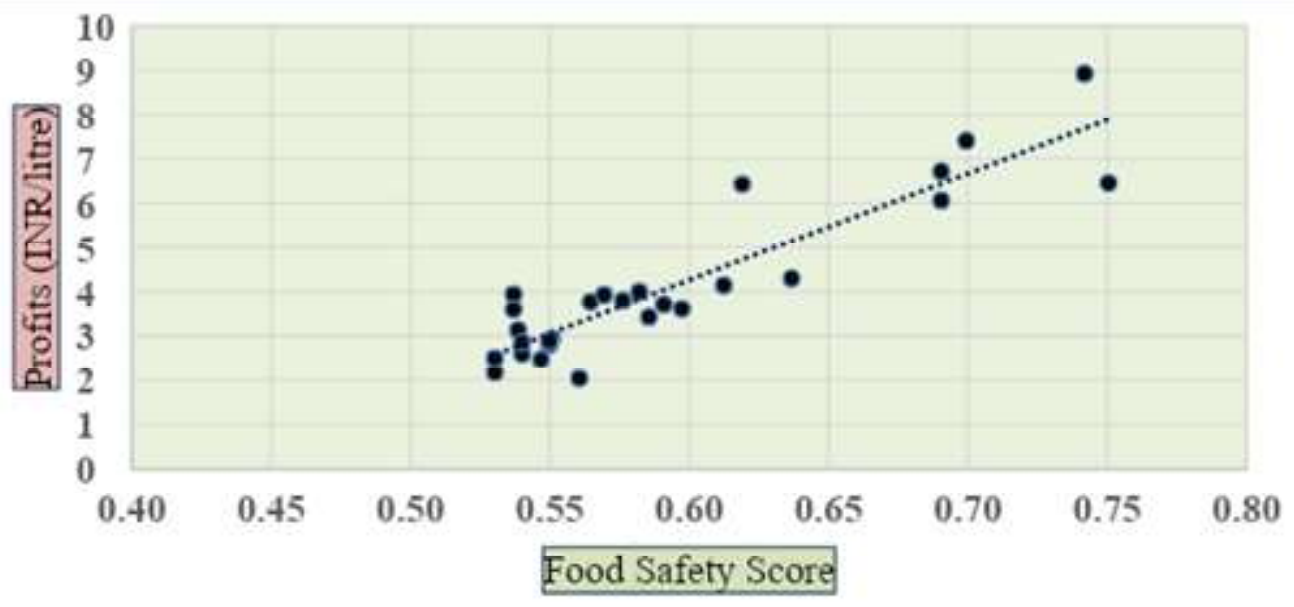

differences exist between the overall indexes of the two value chains.

All the indicators in the index were tested individually among two chains. It has been found that indicators of safety scores as well as overall index values in the own value chain differs significantly from the private vendor chain.

Cut-off scores for classifying the value chains as high, moderate and low adopters were 0.8 (80\%), 0.6-0.8 (60-80\%) and below 0.6 $(<0.60 \%)$, respectively.

Food safety index (FSI) calculated for the milk value chain of own collection centres (0.66) was higher as compared to FSI of private vendors value chain in the study area (Table 2). Value chain of the own collection centres comprises of the farmers who supply milk to the collection centres of processing units. Processing units, who have established collection centres, check the quality of milk (SNF, Fat) at initial stages of the value chains, which meets certain pre-requisites of safety practices. Collection centres has the advantage of milk cooling facility, which reduces the chance of milk spoilage and ensure safe milk transport to the next stage, i.e., processing units. FSI value in case of private vendors' value chain was 0.51 (Table 2). This value chain comprises farmers and private vendors who collect the milk from the farmers and deliver it to the processing units. There is no provision of milk quality check in the initial stages of the chain, although these processing units assess the milk quality at later stage through lactometer test, organoleptic test and checking milk fat and SNF by Gerber test. FSI of own collection centre significantly differ than private vendor chain. To check the statistical difference of safety index values among the identified chains, t-test statistics was applied. FSI of own collection centre was significantly higher than private vendor chain for all selected indicators. This may be on account of unified managementenable strong linkages with dairy farmers, in case of own collection centre value chain, besides underlying factors, viz., processors 
technical knowledge, availability of milk testing and cooling facilities, and timely transport. These collection centres impart knowledge to farmers on food safety issues and act as a bridge between dairy farmers and processing units. Major reason for lower safety index values in private chain was lack of control of processing units over the value chain actors. Private vendors deliver milk directly to the processing units; and hence, no interaction between producers and processors regarding safety issues and milk quality. Milk vendors hardly follow the temperature and time requirement from milk safety standpoint. During survey, it was observed that educated and experienced processors taking care of food safety norms. Further noticed that processing units procuring higher volume of milk than their capacity reluctant towards food safety norms. The training of manpower and actors and adoption of proven processing technology could contribute improvement of FSI in dairy value chain.

\section{Food safety index at farm level}

It has been found that most of the safety practices at the milk producer's level have been implemented, the results collaborate with findings of Kamana et al. (2017) and Kumar et al. (2011). However, the intensity of adoption has been varying among the producers associated with different chains. Food safety practices score for milking and post milking practices was 0.81 (Table 2) for the producers who deliver milk directly either to processing units or their collection centres and in the case of private vendor procurement chain, it was 0.69 . This means that 81 per cent of the safety compliance has been followed in collection centres and $69 \%$ in the private vendor chain. The major difference in the safety scores were attributed to the storage and cooling facility made available at collection centres in the production catchment itself. Use of plastic cans for milk collection and storage has been more common in practice for those who supply milk to the private vendors. Alternatively, metal cans and containers were more used by the producers in own collection centre chain, which reduces the chance of milk contamination (Gashaw et al. 2018).

\section{Food safety index of milk transport and reception}

Critical safety practices under the transportation indicator were rapid cooling of milk, and temperature of milk maintained throughout the transport, which can reduce the microbiological activity, especially bacteria (Gashaw et al. 2018). Rising milk temperature during transportation reduce the milk quality hence rapid cooling after production must be followed to enhance the shelf life of the milk. It has been found that in the chain where milk is delivered to the collection centres which complies with critical safety practices of cooling and transporting milk to the processing units under the temperature requirements $\left(<5^{\circ} \mathrm{C}\right)$ have lesser chances of bacterial growth (Valeeva et al. 2005). Milk value chain of private vendors do not comply with safety regulation of temperature $\left(4-5^{\circ} \mathrm{C}\right)$ (ILRI, 2007) as they do not possess any facility for milk chilling and it takes 5-6 hours for them to reach the processing units which reduces the milk quality (Lemma et al. 2018). Safety score assessed for the transportation activities in collection centres value chain and private vendors chain were 0.59 and 0.46 , respectively (Table 2). Major practices like use of refrigerated vehicles for transportation of milk, insulated bulk containers were not in practice in both the chain and reason for the above was lesser volume of milk handling. Milk quality were satisfactory at farm level but deteriorates most during the transportation from farm to processing units (Kumar et al. 2011).

\section{Food safety index at processing operations and marketing}

FSI values for the processing units were 0.58 (58 \% adoption) and 0.51 ( $51 \%$ adoption) for value chain of direct/own collection and private vendors, respectively (Table 2 ). Critical activities identified in the processing units were to perform the platform test for milk (Organoleptic, lactometer, and alcohol test), operation of cooling, pasteurisation, and use of portable water for products, packaging and storage temperature of different products. Processing units were found to comply with certain critical activities but safety norms like pasteurisation temperature (72 ${ }^{\circ} \mathrm{C}, 15$ seconds) were not monitored in the most of the units. Use of portable water for product preparation were found more in case of owners who are associated with own collection centres. Storage of different dairy products requires different temperatures and dairy processing units hardly found to comply with product specific storage requirements. Major activities identified for processing units were sorting incoming raw materials, trained manpower, unit infrastructure, waste disposal, water management, personal hygiene, record keeping, temperature requirement, regular cleaning schedules. Safety norms like personal hygiene of worker, water and waste management, trained manpower was found inappropriate. Compliance of safety practices were adopted at the lesser level at the processing units who source milk from private vendors. Procurement method of milk by processing units and raw milk processing are critical safety practices which affect safety at processing unit level (Valeeva et al. 2005). Safety practices score in processing operation mainly depends upon the processor's technical knowledge, technology adopted in the processing, infrastructure of units and hygienic conditions maintained in the units.

\section{Food safety index and profit}

Overall, adoption of food safety practices in the value chain is expected to increase the milk quality and finally market prices. Empirical results from the study states that adoption of safety practices is positively and significantly associated with final market prices. Value chains with higher safety index values fetch better prices. Compliance of safety norms at the processing levels are encouraged through premium prices in milk paid by consumers. This establishes the fact that processing units complying with more safety practices (i.e., higher safety index value) leads to higher profits per litre of milk sale (Fig. 4). Hence, it can be said 
that the average milk price differs with adoption level of food safety practices.

\section{Conclusions}

Food safety practices adopted in the milk value chain have been assessed considering two main routes of milk procurement of informal dairy processing units, viz., (i) collection centres, (ii) private vendors. The performance of the processing unit is positively associated with the food safety index (FSI), as consumers are willing to pay higher prices for safe milk. Value chain of own collection centre was found superior in terms of food safety compliance indicating that involvement of one more actor (vendor) has an implication on food safety score. Better the linkages of informal dairy processing units with upstream actors (dairy farmers), better is the food safety compliance.

Hence, institutions like ICAR-National Dairy Research Institute, State Agricultural Universities and other line departments need to take up regular training programmes in post-milking handling. Further, smart milk procurement and transport systems need to be designed and developed for small vendors and processors for food safety compliance in informal milk value chain.

\section{Acknowledgements}

The authors acknowledge the help received from project staff under ICAR-NIAP project on Policy Imperatives for Promoting Value Chains of Agricultural Commodities in India during data collection.

\section{References}

Ali AA and Fischer RM (2002) Implementation of HACCP to bulk condensed milk production line. Food Rev Int 18:177-190

Asselt EV, Spigel MVD, Klerx IVDF, Groot J, Wascher D, Smale E, Verhoeven F, Pintar M, Zasada I, Doernberg A, Piorr A, Sali G, Simiyu R, Kneafsy M (2014) List of selected indicators norms values and framework for assessing food safety and quality. Food Planning and Innovation for Sustainable metropolitan region. Food Meters $1-34$

Bereda A, Zelalem Y, Ajebu N (2012) Hygienic and microbial quality of raw whole cow's milk produced in Ezha district of the Gurage zone, Southern Ethiopia. Wudpecker J Agri Res. 1: 459-465

Burke N, Zacharskil KA, Southern M, Hogan P, Ryan MP, Adley CC (2018) The Dairy Industry: Process, Monitoring, Standards, and Quality. Descriptive food science Intech open 2018.https:// www.intechopen.com/books/descriptive-food-science/the-dairyindustry-process-monitoring-standards-and-quality (web accessed on May 01, 2020) 3-25

Carlsson F, Frykblom P, Lagerkvist CJ (2005) Consumer preferences for food product quality attributes from Swedish agriculture. Ambio 34:366-370. doi: 10.1639/0044-7447

Centre for Science and Environment, (2012) Adulterated milk is what Indians are drinking. https://www.cseindia.org/adulterated-milk-iswhat-indians-are-drinking-3691(web accessed on November 01, 2020)
Chellappa S, Haran G. (2018) Budget 2018: Things to know about Agri, dairy sector and their expectations. Business Standard Jan. 31, 2018. https://www.business-standard.com/budget/article/budget-2018things-to-know-about-agri-dairy-sector-and-their-expectations118013101113 1.html (web accessed on April 22, 2020).

David LO, David LT (2017) Demand for food safety in emerging and developing countries: A research agenda for Asia and Sub-Saharan Africa, J of Agribusiness in Dvp and Emerging Eco, Emerald Group Pub 7: 21-34.doi 10.1111/1471-0307.12322.

FAO (2013) Milk and dairy products in Human nutrition.

FAO (2009) Draft declaration of the world summit on food security. World Summit on Food Security 16-18 November, 2009. Rome.

FICCI (2020) Paper on Development of Dairy Sector in India. Federation of Indian Chambers of Commerce and industry Federation House, Tansen Marg, New Delhi.

FSSAI (2011) https://www.fssai.gov.in/cms/food-safety-and-standardsregulations.php

FSSAI (2011) Training Manual Food Safety Supervisor Course Special (Level 3) - Manufacturing Milk and Milk Product. Safe and nutritious food handbook for dairy sector.

Gandhi VP, Zhou Z (2010) Rising Demand for Livestock Products in India: Nature, Patterns and Implications. Aust Agri Rev 18:103135

Gashaw A, Gebrehiwot E (2018) Study on Milk Hygiene, Quality Control in the Market Chain in Jimma. J Adv Dairy Res 6: 213. doi: 10.4172/ 2329-888X.1000213.

Giffel MC, Wells-Bennik MHJ. (2010) Good hygienic practice in milk production and processing in Improving the Safety and Quality of Milk. Wd Pub Series in F Sci Tech \& Nutri. Mansel W. Griffiths, ed. Woodhead Publ, Cambridge, UK. Pages 179-193 https://doi.org/ $10.1533 / 9781845699420.2 .179$.

GoH (Government of Haryana), (2019) Econ Survey of Haryana 201819. Publication No.1205, Dept of Econ and Stat Analysis, Planning Division, $\mathrm{GoH}$.

Griffiths MW. (2010) The microbiological safety of raw milk, in Griffiths, M.W. (Ed.), Improving the safety and quality of milk: Milk production and processing. Wd Pub Ltd, Oxford, UK, 1: 27-63.

Gupta S, Kumar NR, Krishnan M, Immanuel S (2014) Impact of Compliance with Food Safety Measures in Fish Processing Units. Fishery Technol 51:261-266

Handschuch C, Wollni M, Villalobos P (2013) Adoption of food safety and quality standards among Chilean raspberry producers-do smallholders' benefit? Food Policy 40:64-73

International Livestock Research Institute (ILRI), (2007) Comprehensive study of the Assam (India) dairy sector: Action plan for pro poor dairy development. https://cgspace.cgiar.org/handle/10568/1148/ browse (web accessed on May 01, 2020).

Janssen E, Swinnen J (2019) Technology adoption and value chains in developing countries: Evidence from dairy in India. Food Policy 83:327-336. https://dx.doi.org/10.1016/j.foodpol.2017.08.005

John M (2012) Managing high grade dairy cows in the tropics. CSIRO Pub Cllingwood Australia.pp 162-171.

Kamana O, Liesbeith J, Anastase K, Uyttendaele M (2017) A survey on hygienic practices and their impact on microbiological quality and safety in the Rwandan milk and dairy chain, Rwanda. Int J Dairy Technol 70: 52-67

Kohli C and Garg S (2015) Food Safety in India: An Unfinished Agenda. MAMC J Med Sci1: 131-135

Kumar A, Mishra AK, Saroj S, Sonkar V, Thapa G, Joshi PK (2020) Food safety measures and food security of smallholder dairy farmers: Empirical evidence from Bihar, India. Agribusiness, 36:363-384. DOI: 10.1002/agr.21643. 
Kumar A, Staal SJ, Singh DK (2011) Smallholder Dairy Farmers'Access to Modern Milk Marketing Supply Chain in India. Agri Eco Res Rev 24: 243-253

Kumar A, Thapa G, Roy D, Joshi PK (2017) Adoption of food safety measures on milk production in Nepal: Impact on smallholders' farm-gate prices and profitability. Food Policy 70:13-26.

Kumar D, Rai D, Porwal P, Kumar S (2018) Compositional Quality of Milk and Its Contaminants on Physical and Chemical Concern: A Review. Int J Curr Microbial App Sci 7: 1125-1132. doi: https:// doi.org/10.20546/ijcmas.2018.705.137

Lemma DH, Mengistu A, Kuma T, Kuma B (2018) Improving milk safety at farm-level in an intensive dairy production system: relevance to smallholder dairy producers. Food Quality Saf 3:135-143

Malathi G, Prasad RS (2017) Total Quality Management in Indian Dairy Industry (A Comparative Study on Select Units in Dairy Industry). IOSR J Bus Mngt 19: 3-17

Marette S, Roosen J, Blanchemanche S, Verger P (2008) The choice of fish species: An experiment measuring the impact of risk and benefit information. J Agric Resour Eco 33:1-18

Murphy SC, Martin NH, Barbano DM, Wiedmann M (2016) Influence of raw milk quality on processed dairy products: How do raw milk quality test results relate to product quality and yield? J of Dairy Sci 99: 10128-10149

National Dairy Development Board (NDDB) (2016) Guidelines for Award of Quality Mark for Milk

NDDB (2017) https://www.nddb.coop/information/stats/milkprodindia

Pandey GS, Voskuil GCS. (2011) Manual on milk safety, quality and hygiene. Golden Valley Agri Res Trust, Zambia 50:1-52

Reardon T, Timmer CP (2014) Five Inter-Linked Transformations in the Asian Agri-food Economy: Food Security Implications, " Global Food Sec 3: 108-117

Ruxton DG (2006) The unequal variance $t$-test is an underused alternative to Student's $t$-test and the Mann-Whitney $U$ test, Behavioural Ecol 17:688-690.https://doi.org/10.1093/beheco/ark016
Shamsuddoha M, Nedelea A (2013) A Vensim based analysis for supply chain model. Ecoforum 2:49-54

Singh KP, Singh RRB, Singh I, Kundu KK, Sirohi S, Dixit AK (2017) Doubling farming income in Haryana by 2022- A Strategy document, prepared by CCSHAU, Hisar and ICAR- National Dairy Research Institute, Karnal, pp.163

Statistical Abstract of Haryana, 2017-18. Dept of Econ and Stat Analysis, Haryana, 2019.

Tadele A, Mitiku E, Yoseph M, Ameha K (2016) Milk postharvest handling practices across the supply chain in Eastern Ethiopia. J Adv Vet Anim Res 3: 112-126

Thakur A, Dixit AK, Kumar S, Bhandari G (2021) Value Chain Analysis of Informal Dairy Processing Units in Haryana (India): A System Dynamic Approach. Agric Res 10:307-313. https://doi.org/10.1007/ s40003-020-00502-2

Unnevehr L (2014) Food safety in developing countries: moving beyond exports. Global Food Sec 4:24-29

USDA, Econ Res Serv (2017) India's Dairy Sector: Structure, Performance, and Prospects. Livestock, Dairy, and Poultry Outlook No. (LDPM272-01) 49pp. https://www.ers.usda.gov/publications/pub-details/ ?pubid $=82638$

Valeeva NI, Meuwissen MPM, Oudelansink AGJM, Huirne RBM (2005) Improving food safety within the dairy chain: An application of conjoint analysis. J Dairy Sci 88:1601-1612 